\title{
The history of transdisciplinary race classification: methods, politics and institutions, 1840s-1940s
}

Richard McMahon*

\begin{abstract}
A recently blossoming historiographical literature recognises that physical anthropologists allied with scholars of diverse aspects of society and history to racially classify European peoples over a period of about 100 years. They created three successive race classification coalitions - ethnology, from around 1840, anthropology, from the 1850s, and interwar raciology, each of which successively disintegrated. The present genealogical study argues that representing these coalitions as 'transdisciplinary' can enrich our understanding of challenges to disciplinary specialisation. This is especially the case for the less well-studied nineteenth century, when disciplines and challenges to disciplinary specialisation were both gradually emerging. Like Marxism or structuralism, race classification was a holistic interpretive framework, which, at its most ambitious, aimed to structure the human sciences as a whole. It resisted the organisation of academia and knowledge into disciplines with separate organisational institutions and research practices. However, the 'transdisciplinarity' of this nationalistic project also bridged emerging borderlines between science and politics. I ascribe race classification's simultaneous longevity and instability to its complex and intricately entwined processes of political and interdisciplinary coalition-building. Race classification's politically useful conclusions helped secure public support for institutionalising the coalition's component disciplines. Institutionalisation in turn stimulated disciplines to professionalise. They emphasised disciplinary boundaries and insisted on apolitical science, thus ultimately undermining the 'transdisciplinary' project.
\end{abstract}




\section{Introduction}

Academic disciplines gradually emerged in the nineteenth century, progressively professionalising, specialising and establishing organisational institutions and preferred evidence-types and study-objects. ${ }^{1}$ The 'quite amateurish' American Social Science Association (f. 1865) was, for example, supplanted by separate bodies for history in 1884, economics in 1885, political science in 1903 and sociology in $1905 .^{2}$ Scientists who practised the research that we now associate with physical anthropology resisted this disciplinary differentiation. They allied with scholars of diverse aspects of society and history to classify European peoples by biological race. Scholars of skeletal material, modern 'physical and psychological characteristics', language 'vestiges', written histories and folklore, were all eager to contribute. ${ }^{3}$ A recently blossoming historiographical literature on scientific race classification therefore widely recognises that its three successive projects were coalitions. ${ }^{4}$ Ethnology was organised around 1840, followed by anthropology from the 1850s, and then interwar raciology

Race classification proposed a holistic interpretive framework, which, at its most ambitious, aimed to structure the human sciences as a whole. Its coalitions of cultural and biological scholars thus challenged the emergent model of organising knowledge and research into separate disciplines. Any variant of the word discipline is somewhat anachronistic until the late nineteenth century. This article nevertheless argues that the three race classification projects had a great deal in common with later 'transdisciplinary' movements. The term ‘transdisciplinary’ was coined in 1970 and after the Cold War, transdisciplinarity blossomed into a holistic programme for academic reform. ${ }^{5}$ The movement sought to tackle complex real 
world challenges by transgressing disciplinary boundaries and identifying 'deep structures'. Many historians of science locate it within a longer history of holistic transdisciplinary projects, including Marxism and structuralism. ${ }^{6}$

Deliberately adopting the anachronistic concept of transdisciplinary coalitions can enrich our understanding of the complex imperatives for the development of scientific knowledge, and also of historical challenges to disciplinary specialisation. A growing literature examines the periodic waves of academic enthusiasm for interdisciplinarity since the 1920s, which, for example, produced Area Studies in the 1940s and Cultural Studies in the 1950s. ${ }^{7}$ Interdisciplinarity was most recently stimulated by the 1990s critique of the 'academic closure and corporatist privileges' of disciplines. ${ }^{8}$ The present article, however, examines the origins of academic disciplines in the less well studied nineteenth century. ${ }^{9}$

Race classification organised its coalitions in the - at best - proto-disciplinary, middle decades of the century. Separate social sciences were simultaneously and very gradually crystallising around sets of research practices and early institutions. ${ }^{10}$ The Geographical Society of London (1830) preceded the first ethnological society (1839), and regular international anthropology congresses began in 1865, three decades before those of the emerging disciplines of history and sociology. ${ }^{11}$ Historians and sociologists of science criticise the 'remarkably' patchy, limited and divided historical literature on this period. ${ }^{12}$ In particular, 'presentist' tendencies encourage historiography to focus on the past of currently existing academic disciplines, often representing them as 'relatively stable and delimited' since the nineteenth century. ${ }^{13}$ Chris Manias, for example, states that histories of the amorphous fields participating in race classification tend 'to take current academic disciplines as natural'. ${ }^{14}$ Others focus on defenders of either gentlemanly amateurism or of the unity of science or natural philosophy. ${ }^{15}$ 
The present article, by contrast, aims to de-essentialise disciplines and transdisciplinary coalitions by using some elements of a 'genealogical' approach. Therefore, unlike the many historians who examine 'interdisciplinary' nineteenth-century resistance to disciplinary specialisation purely in terms of ideas, ${ }^{16}$ I investigate the historically contingent development of race classification's institutions and practices. ${ }^{17}$ This includes the continuous tension between disciplinary and transdisciplinary impulses. To a greater or lesser degree, individual race classifiers specialised in the specific sets of research practices and research objects that eventually came to define disciplines such as physical anthropology, cultural anthropology, archaeology or linguistics. However, they also tried to organise all these 'proto-disciplinary' practices into a common transdisciplinary programme of race research on nations. The resistance provoked by these transdisciplinary ambitions acted as a crucial formative experience for emerging disciplines. Laurent Mucchielli for example describes how complex boundary struggles with contemporary physical anthropology shaped Émile Durkheim's sociology and Marcel Mauss's anthropology. ${ }^{18}$

My genealogical approach therefore challenges conventional assumptions, which owe much to disciplinary traditions, that the economy, politics, culture and so on are naturally separate and autonomous social realms and a self-evident basis for organising academia. A genealogical approach also highlights how dynamics of power and competing interests shaped the development of transdisciplinary coalitions. ${ }^{19}$ Because political interests were as important to race classification as scientific ones, race classification did not just challenge the emerging borderlines among scholarly disciplines, but also those dividing science from politics. I therefore do not just examine developments in methodology and race theory. I also systematically trace sociological and political reasons for the forging and disintegration of 
coalitions, related to discipline formation, public support for academic institutions and political agendas. Like must current sociology of science, I found there was a constant interchange between these 'internal' scientific and 'external' sociological/political factors. ${ }^{20} \mathrm{~A}$ political, real-world vocation has thus been central to several transdisciplinary projects. ${ }^{21}$ UNESCO and the EU have, for example, been key sponsors of the post-1970 transdisciplinary movement, which emphasises the social application of research. ${ }^{22}$

In the century of race classification, race biology was widely seen as the key to understanding modern society, and especially the nation and its politics. Benjamin Disraeli told the British Parliament in 1849 that Race implies difference, difference implies superiority, and superiority leads to predominance'. ${ }^{23}$ One British anthropologist declared in 1869 that legislation 'must respect racial distinctions and characteristics, or it will be a disastrous and mischievous failure' ${ }^{24}$ Confident positivist science contributed to the intensive racialisation of emergent mid-nineteenth-century national identities. Associations, journals and books popularised natural science and race among the middle-classes. ${ }^{25}$ Politicians and the public rewarded classifiers for giving nations scientific validation and positive associations with the Aryan race, Europeanness, evolutionary advancement, modernity and desirable psychological traits. Race also offered nations the prestige of antiquity, extending their biological roots deep into prehistory. Historians widely recognise the political vocation of racist interwar raciology, which legitimated xenophobic extreme nationalism. ${ }^{26}$ However nineteenth century ethnology and anthropology were equally fixated on the racial identity of nations.

The project of connecting nations with races required ‘interdisciplinary’ collaboration between scholars of biology and culture, because people largely experienced and understood nations through non-biological factors such as national character, society, politics and geopolitics. This 
entwined politics in intricate ways with changing practices of race classification, discipline formation and 'interdisciplinary’ coalition-building. In particular, politics was key both to race classification's simultaneous longevity and to its unstable succession of ethnological, anthropological and raciological coalitions, lasting over a century. First, politics acted as a powerful transdisciplinary glue. Despite the successive collapse of ethnological and then anthropological alliances, the public continued to demand race classification. Resources were, therefore, available to establish institutions for eclectic new scholarly alliances with new evidence sources and research techniques. In two major international waves, after 1839 and 1859, ethnologists and then anthropologists established national and international societies, journals and conferences. Numerous professorial chairs followed from the mid-1870s. These proliferated further after 1918, especially in newly independent countries and under fascist regimes. ${ }^{27}$

However, public resourcing of academic institutions also stimulated the disciplinary specialisation that twice tore the classification project apart. As Ellen Messer-Davidow et al. note, 'university departments, professional societies, text-books and lab manuals' increasingly tended to reinforce disciplines as 'the infrastructure of science'. ${ }^{28}$ Institutions defined and circumscribed emerging disciplines and fixed their names and interrelations. Differing research traditions and evidence sources pulled disciplines towards divergent and often incompatible research methods and questions. They professionalised, gained in confidence and insisted on the autonomy of science from politics. Strengthening disciplinary boundaries, therefore, also excluded popular race theorising. All this pulled disciplines away from the eclectic race classification coalition. The well-known scientific unfoundedness of the race concept, therefore, only partly explains the successive disintegration of the three successive race classification projects. 
This article examines transdisciplinary organisation and concrete practices of classifying Europeans in the three successive phases of race classification. I first briefly sketch ethnology’s eclectic coalition, largely on the basis of secondary sources. I then use mostly primary research, including systematic investigation of race classification institutions and citation, to examine nineteenth-century anthropology. ${ }^{29}$ I supplement this with secondary literature on disciplinary history. Using a similar research base, I trace how interwar raciology used new political ideologies to stay the rising tide of disciplinarisation. While nineteenth-century anthropology was structured around a disciplinary and geographical core, however, raciology was much more part of a complex multipolar ecology of multiple right-wing coalitions.

\section{Ethnology}

After William-Frédéric Edwards founded the Paris Ethnological Society in 1839, similar bodies sprang up in New York (1842) and London (1843), bringing together students of biology, history, antiquities, language and geography. ${ }^{30}$ Historians therefore widely recognise that ethnology tightly organised an important section of the proto-social sciences around race classification. $^{31}$

Claude Blanckaert argues that physicians such as Edwards and J.C. Prichard in England established ethnology by synthesising the two distinct race study traditions of Enlightenment biology and Romantic nationalist history, geography and philology. ${ }^{32}$ Enlightenment zoological classifiers of species identified global (White, Black, Caucasian, Mongoloid etc.) race categories. These zoologists became, with other 1770s-90s naturalists, the 'accredited' scientific race specialists. ${ }^{33}$ Comparative anatomists such as Johann Friedrich Blumenbach were increasingly prominent among them. Following the American and French revolutions 
meanwhile, 'linguistic-geographers, travellers, naturalists, and historians' began turning European attention from 'great men' to national populations, strengthening the rising social belief that race determined culture. ${ }^{34}$ Romantic historians such as Amédée Thierry distinguished the 'peoples who constituted the nation,' uncovering 'ethnic and organic factors underneath cultural practices and social revolutions’.35

Positivist, medically and biologically-trained race classifiers determined unambiguous positive 'facts'. This offered more institutionally precarious scholars of culture an association with the immense prestige of natural science. ${ }^{36}$ From 1800, and especially in the period 1860-1915, as the medical profession dramatically expanded in numbers and influence, biological and racial 'concepts, methodologies, metaphors, "laws,”' and attitudes powerfully influenced 'softer' scientific disciplines. ${ }^{37}$

Ethnology aimed to subordinate classification of 'nations' by language, customs or 'aptitude for civilisation’ to biology. ${ }^{38}$ However, its early techniques for studying physical races and reconstructing their past were 'essentially impressionistic'. ${ }^{39}$ Edwards, for example, mostly just travelled about observing 'the form of the head and the proportions of the facial features' of passers-by. ${ }^{40}$ By contrast, early nineteenth-century German linguists had made comparative philology the 'regnant' human science ${ }^{41}$. Only a minority of ethnologists ever had more than a superficial understanding of philology's difficult techniques. Nevertheless, this systematic, reliable and widely accepted scientific method became their main race classification method until the 1860s. ${ }^{42}$ Philologists used regularities in historical sound changes to work out the family trees of languages. To an extent, they could also tell when and where languages diverged from one another. At the dawn of nationalism, when language communities were widely assumed to be biological races, this project was deeply political. Prichard, a leader in both 
physical anthropology and philology, gave particular prominence to languages, insisting that they were reliably inherited within biological descent groups. Environmental factors, by contrast, could transform biological features rapidly. Philology also provided ethnology's core classification. This derived most Europeans from the race whose prehistoric invasion from Asia introduced Indo-European or Aryan languages to the continent.

'External' political and 'internal' scientific factors both drove the transition from ethnological to anthropological societies in Britain and France after 1848. Blanckaert argues that the socially reforming Saint-Simonian backers of the Paris Ethnological Society got it embroiled in the 1848 Revolution. ${ }^{43}$ Napoleon III’s government closed the society. In 1859, Paul Broca founded the Paris Anthropological Society on the night when his speech on animal hybridisation at the Biology Society was stopped mid-way for fear of its applicability to human races. ${ }^{44}$ Across the Channel, Broca’s society inspired a new generation of radically racist, colonialist and anti-Irish archaeologists and craniologists to break away from the liberal London Ethnological Society. ${ }^{45}$ In 1863, they established the more anatomical and race-oriented Anthropological Society. ${ }^{46}$

Turning to 'internal' scientific factors, highly cited medical school anatomists such as Blumenbach and, in the 1840s, Anders Retzius and Samuel Morton, made craniology the central race classification method. ${ }^{47}$ They usually identified typical national race types on the basis of small studies of a few dozen, or even just a handful of 'representative' ancient crania. ${ }^{48}$ Dr William Wilde, father of Oscar, thus 'at once pronounced to be ancient Irish', some Etruscan skulls in a Paris museum, much to the hilarity of his hosts. ${ }^{49}$ Museums, which were often the earliest anthropological institutions, encouraged this biological approach. Race anthropologists, following anatomical and zoological models, taught, classified, theorised and 
publicised their theories by arranging series of skulls and skeletons in museum collections. ${ }^{50}$ Mass surveys of living Europeans only began to challenge this approach in the 1860s-1870s.

Crucially, in 1840, Retzius established the 'unanimously celebrated and adopted' standard race measure 'upon which the whole of modern craniometry is based'. ${ }^{51}$ This was the distinction between long (dolichocephalic) and broad (brachycephalic) skulls, as seen from above. Race classifiers used it to insert their studies of 'national' crania into international comparative schemes. Retzius himself distinguished Aryan dolichocephalic Western Europeans from brachycephalic pre-Aryan Eastern Europeans.

\section{Anthropology}

In the 1860s-1890s, a steady succession of new anthropological societies welcomed floods of members and issued a stream of publications, especially in western and northern Europe. ${ }^{52}$ Positivist biologists aimed academically to consolidate an anthropological project of great breadth. This made eclecticism inevitable. Their natural histories were holistic. They embraced humanity's origins, age, distribution, physical form, 'relation to animals' and environment, biological laws, 'degrees of intelligence', 'susceptibility of cultivation', beliefs, laws, customs, art, language, and 'material culture' ${ }^{53}$ Within this broader scope of anthropological projects, they redefined ethnology - the history, geography, biology, psychology, culture and evolution of races - as a subdivision. ${ }^{54}$ The new anthropology researched issues such as childhood development, which were 'not of ethnic significance'. ${ }^{55}$ However, racial ethnology remained central, especially for maintaining interdisciplinary alliances. Shared interests and natural scientific training tightly linked ethnologists and anthropologists, even in their rival British societies. $^{56}$ 
Anthropological sections in bodies such as the British Association for the Advancement of Science (BAAS - founded 1831) and later in 'omnibus' anthropological societies, and chairs in multi-professorial Parisian and Viennese anthropology schools, played an important but ambiguous role in the developing organisation of scholarship. ${ }^{57}$ They simultaneously reinforced the emerging disciplinary identities of linguists, prehistorians, geographers and archaeologists while institutionalising interdisciplinary links. Germany’s anthropological society, established in 1870, for example, had sections for (physical) anthropology, (cultural) ethnology and prehistory. In the 1870s, the physical anthropologist and prehistorian Rudolf Virchow alternated as its president with the ethnologist Adolf Bastian, who collected 'customs and traditions... of vanishing tribes'. From 1900, my research shows that race classifiers cited professors of ethnology and other allied disciplines most often after anthropologists. Basing anthropology in natural science sections of university philosophy faculties rather than medical faculties allowed German, Scandinavian and Austria-Hungarian biological and cultural anthropology to co-exist. ${ }^{58}$ Interwar central European 'Anthropology and Ethnology' departments were established to resist the centrifugal forces of specialisation.

Nevertheless, the anthropology established in societies from 1859 on was more biology-centred than ethnology had been. The BAAS classed anthropology under biology in 1866, but left ethnology within geography. ${ }^{59}$ The physical anthropology section of Germany's Anthropological Society was 'older and larger' than its ethnological or prehistorical branches. ${ }^{60}$ Numerous anthropologists were medically-trained, including 16 of 19 founders of the Paris Anthropological Society (1859), all three original leaders of the 1926 German physical anthropology society, and many interwar Polish race classifiers. ${ }^{61}$ Virchow was the 'internationally known... founder of cellular pathology'. ${ }^{62}$ Broca, a professor of surgery, identified a speech production region of the brain that is still called Broca's area. ${ }^{63}$ 
Like other professionalising and specialising social sciences, anthropology embraced positivist natural science to copper-fasten its disciplinary independence. ${ }^{64}$ Craniologists declared that they built their research paradigm around measuring and classifying physical races 'to emancipate anthropology from the "tyranny of the linguists"”, ${ }^{65}$ The vogue for Aryan theories and a powerful new biologism in linguistics after the mid-century boosted the influence of linguistic race classification, however. Neogrammarian linguists portrayed languages ‘as living organisms' and used sophisticated sound law analysis to reconstruct extinct tongues. They even claimed to identify culture and geography from reconstructed vocabularies for trees, crops, metals and so on. ${ }^{66}$

Physical anthropologists fought back. Retzius initially aligned skull-type with the Aryan theories of 'more robust, more adult and better-fed' philology. ${ }^{67}$ However he systematically prioritised craniology when anthropometric (body measurement) and linguistic evidence repeatedly clashed during the 1840s-1850s. Ancient crania and animal cross-breeding convinced positivist anthropologists that physical and especially skeletal traits were more reliably inherited and fixed to ethnic groups than languages were. ${ }^{68}$ They noted that Europe's Indo-European speakers physically resembled the linguistically non-Indo-European Finns much more than Indo-European Indians. ${ }^{69}$ Anthropologists warned that linguistics, 'a beautiful and difficult science, born yesterday,' would inevitably favour linguistic over physical characteristics. ${ }^{70}$ They mocked wild philological claims that, for example, Malay and Semitic were Indo-European.

Physical anthropologists won a crucial victory over philology in the 1860s, cementing their role at the core of race classification. This battle within the Paris Anthropological Society 
concerned France's supposedly Celtic racial ancestors. Its outcome was that Celts were established as broad-headed brunets, like most modern French, and as native Europeans rather than as long-headed blond Aryans from Asia. The dispute is striking for the diversity of cultural, linguistic, artefactual and anatomical evidence marshalled by protagonists on all sides. ${ }^{71}$ However even the losers conceded that craniology rather than artefactual evidence should 'pronounce the last word'. ${ }^{72}$

Large-scale craniological surveys of living populations, which became a signature technique of race anthropology, demonstrated that the indisputably Celtic Bretons were mostly broadheaded. ${ }^{73}$ However, the rapid expansion and professionalisation of prehistoric excavations across Europe, especially of tombs, was even more important in this 1860s dispute. The new discipline of prehistoric archaeology borrowed physical anthropology’s positivist natural scientific models. In a key interdisciplinary realignment, Retzius and other Scandinavians pioneered a new alliance in the 1840s, in which prehistoric archaeology replaced philology as anthropology’s main ally in race history research ${ }^{74}$. Ancient graves and museum research both juxtaposed ancient skulls with artefactual evidence of the stone-bronze-iron Three-Age System, which had been theorised in the 1820s. Archaeologists, therefore, initially interpreted their 'remarkable' 1860s-1880s discoveries, including Neanderthal and Crô-Magnon, in terms of European race history rather than evolution. ${ }^{75}$

Linguists such as Franz Pruner-Bey implacably defended an older, language-centred ethnological complex of ideas. This included Prichard's position that physical type was mutable, while language was an inalienable fixed point, almost 'never communicated' between races. ${ }^{76}$ These linguists tried to insert language into the now-dominant physical race paradigm. Pruner-Bey claimed pre-Roman races physically 'prepared' the mouth 'to mould Latin 
words'. ${ }^{77}$ By the 1870 s, however, leading linguists such as Abel Hovelacque, confident of their own techniques, agreed with physical anthropologists that the two disciplines produced separate, independently valid classifications. ${ }^{78}$ Though many naturalists were by then utterly ignorant of philology they often still assumed that each biological race had its own language in the distant past. They continued to use linguistic evidence, like history, as an 'indispensable' subordinate ‘auxiliary'. ${ }^{79}$

Prehistoric archaeology therefore helped anthropology to overcome a 1860s crisis caused by the growing disciplinary independence of race biologists and linguists. Transdisciplinary positivist anthropology thrived for another three decades. During this time, however, disciplinary specialisation and self-awareness intensified.

\section{Anthropology's interdisciplinary alliance disintegrates}

An analysis of citation suggests that in the 1870s-90s, the international literature on European races crystallised around a narrow canon of mostly Francophone standard authorities. ${ }^{80}$ In a period of rapid international integration of science, agreements in 1906 and 1912 standardised anthropometric measures. Nevertheless, citation practices progressively fragmented after 1900. ${ }^{81}$ Anthropology's interdisciplinary alliance of biological and cultural scholars disintegrated. ${ }^{82}$

From 1880, but especially after 1910, new Americanist, Africanist, sociology, folklore, linguistics and especially prehistoric societies and provincial and international anthropology societies sapped portmanteau national anthropological societies. ${ }^{83}$ Physical anthropology, overseas cultural anthropology, and European folklore divorced institutionally and theoretically. ${ }^{84}$ Nationalist German and central European prehistoric archaeologists such as 
Gustaf Kossinna in Berlin successfully achieved university chairs in 1889-1913. They shifted archaeology away from natural science and back towards its earlier association with history, favouring cultural rather than skeletal evidence. ${ }^{85}$ By 1931, many prehistorians advocated separate international conferences from the anthropologists. ${ }^{86}$

Interacting internal and external factors encouraged this disintegration of anthropology's race classification coalition. A widely recognised internalist explanation emphasises craniology’s scientific failure. Its ‘orgy of quantification’ from the 1860s on, including increasingly precise anthropometric surveys, a profusion of competing techniques and 'over six hundred different measuring instruments', produced meagre definitive results. ${ }^{87}$ By 1900 , researchers had recorded about 25 million anthropometric measurements in Europe, mostly of schoolchildren plus some military recruits. ${ }^{88}$ By the 1890 s, however, competing race taxonomy hierarchies had produced a 'hopeless chaos' and several studies undermined key assumptions. ${ }^{89}$ With no major scientific breakthrough in sight, senior scientists began to question the entire project.

As professional scientists, anthropologists accepted mounting evidence against the links between physical types and cultural nations that their eclectic coalition was established to explain. Anthropological research after 1840, and especially Virchow's massive 1875 survey of German schoolchildren, demolished Romantic period ethnological assumptions that nations were racially homogeneous. Anthropologists first accepted modern nations as mixtures of pure race individuals and then conceded that most modern Europeans were 'multiple racial crosses' ${ }^{90}$ Only statistical analysis could, therefore, tease out their 'ethnic elements'. By 1900, physical anthropologists were questioning the theoretical bases of both race and atavism, the mechanism that supposedly repurified race mixtures after cross-breeding. ${ }^{91}$ Some were shifting to non-racial interests such as growth and development. They increasingly discarded descent 
as a criterion for defining races, despite its indispensability for nationalist race history, and reduced races to statistically occurring physical types in present-day populations. ${ }^{92}$ Geographical race names such as Mediterraneans and Nordics replaced ethnic terms such as Celtic and Germanic. The Polish anthropologist Kazimierz Stołyhwo thought even Nordic too ethnically specific and suggested Homo fanotrichus glaukops dolichocephalus instead, abbreviated to skotodolichocephalus for convenience. ${ }^{93}$

Theories of original race purity were the last scientific defence of European national races. Biological races somehow 'belonged' to their original ethno-linguistic groups. For the raciologist Hans F.K. Günther therefore, the tall, blond long-headed Nordic was the ‘irreplaceable’ nucleus of Germanic cultures. ${ }^{94}$ This made cultural change illegitimate. It was embarrassing, for example, for dolichocephalic Poles to be 'culturally but not anthropologically Slavic'. ${ }^{95}$ Very dark or fair pigmentation or extreme values in stature or skull dimensions were presumed to be surviving traits of the original pure races. However, scientific research progressively complicated the initially simple ethnological linkage of ethnic nations with unchanging, pure physical race types that stretched back to prehistoric craniological types such as the Crô-Magnon. ${ }^{96}$ Around 1900, 'very heterogeneous' skulls were discovered among isolated tribesmen and prehistoric Swedes. This led most anthropologists very reluctantly to abandon their belief that prehistoric peoples and modern 'savages' were more physically homogenous than civilised people and that even medieval European nations may still have been racially pure. ${ }^{97}$

I argue that race anthropology's sociological characteristics offer another important explanation for its decline. This interdisciplinary coalition was a victim of its own success in generating public interest, thriving societies and ultimately, political support for that holy grail 
of scholars, university jobs. Societies of enthusiasts and the journals and national and international conferences they organised were vitally important for building communities for race classification. ${ }^{98}$ However, only state-sponsored institutions could provide structured careers and professional recognition. ${ }^{99}$ Widespread university institutionalisation of anthropology began in the 1870 s, twenty years later than in archaeology. ${ }^{100}$ Florence established the first university anthropology chair in 1869. In 1876 the six chairs of Broca's Ecole d'Anthropologie made it the world's largest anthropology teaching institution. ${ }^{101}$ Bibliographical data suggests that the establishment of anthropology and ethnology as academic disciplines made anthropology professors, especially from Broca's Ecole, the key race classification authorities after $1860 .{ }^{102}$ By the twentieth century, however, practicing physicians faded into the background. An exception is the army surgeons who carried out statebacked anthropometric surveys of millions of military recruits and World War I prisoners ${ }^{103}$.

Professionalisation undermined interdisciplinarity. Disciplines with new national institutions and rapidly growing cohorts of scholars depended less on other disciplines and became increasingly concerned with defining and policing their boundaries and distinctive content. ${ }^{104}$ Following the example of philology, they honed core methodologies and focused on issues arising from them. Even in the 1870s heyday of positivist interdisciplinarity, therefore, patterns of citation suggest a distinct cultural ethnology canon. ${ }^{105}$

Whereas Broca's generation saw positive scientific facts as interchangeable bricks in an edifice of knowledge, experience gradually showed that 'disparate approaches' produced 'conflicting answers' ${ }^{106}$ Linguists, archaeologists and physical anthropologists, for example, rejected one another's conclusions on the politically crucial Aryan question. Controversies within specialised disciplines made it hazardous to borrow results from or comment on other fields. ${ }^{107}$ 
Each 'jealously monopolized its right to speak in its own name' and to judge its members' scientific competence.

Physical anthropologists themselves professionalised and specialised, largely replacing anatomists as physical anthropology teachers in German universities in 1900-25. ${ }^{108}$ They increasingly felt constricted by the old interdisciplinary alliance, ignored culture and criticised the influence of prehistorians in anthropological institutions. ${ }^{109} \mathrm{~A}$ more narrowly focused new Physical Anthropology Society (founded 1925) superseded the eclectic German Anthropological Society, which dissolved in 1936. Physical anthropologists took over many German, Swiss and central European 'anthropology' chairs and often moved them into university medical faculties. ${ }^{110}$ Ethnology, linguistics and archaeology were left behind in philosophy.

Political factors also weakened race classification. Anthropology’s dominant liberal ideology undermined the linkage of race with political ethnicity and therefore the transdisciplinary alliances between scholars of biology and culture. Several anthropologists blamed neglect of race, which caused public interest and funding to wane, for the late nineteenth-century decline of French and British physical anthropology. ${ }^{111}$ The preference of liberals for cosmopolitan urban modernity undermined the political usefulness of their racial narratives. Liberals often represented nations as racial mixtures or fusions rather than as ethnocentric national races.

Liberal insistence on an apolitical positivist ideology of science also worked against blatant politicisation of race. After failed nineteenth-century revolutions, liberals living under autocratic rule in Germany, Russia and Poland saw the ostensibly apolitical ‘organic work’ of science as their only feasible means of transforming society. In 1865, for example, Bismarck 
humiliated Virchow by challenging him to a duel, and thereby forcing him to apologise during a political dispute. Virchow's response was that 'if I must work for the future, I'd rather do it through science than in pseudoparliaments'. ${ }^{112}$ Some scholars from geographically marginal parts of the transnational scientific network, such as Ireland or the Balkans, particularly insisted on apolitical professionalism to secure international respectability. ${ }^{113}$

Liberal anthropologists therefore progressively delegitimised 'philosophical ethnology', which, in its 1840s-1860s heyday, exploited new mass marketing techniques to popularise and sloganise scientific racism. ${ }^{114}$ Popular works by the ex-diplomat Arthur de Gobineau, the historian Ernest Renan, the literary critic Matthew Arnold, and others in this period identified races with nations or even political causes such as the French Revolution. ${ }^{115}$ Gobineau developed a full-blown racial philosophy of history and even some medical scholars, such as Robert Knox in Britain, produced racist and overtly political work. Societies, which were anthropology’s initial institutional base, created space for philosophical ethnology by prioritising a very broad membership. ${ }^{116}$ The Paris Anthropological Society, for example, welcomed Renan and the hugely popular psychologist Gustave Le Bon as members. ${ }^{117}$

Histories of anthropology show how the professional discipline made these dilettantes increasingly unwelcome. ${ }^{118}$ Radical xenophobes were in a minority after Britain's anthropologicals and ethnologicals merged societies in $1871 .{ }^{119}$ Contemporary French and German anthropology barely tolerated Nordic supremacism. French, German and Russian anthropology marginalised racist, anti-Semitic extremists in the 1890s. Durkheimians allied with consciously apolitical and left-wing physical anthropologists to demolish the race paradigm within French anthropology after the 1900 political defeat of anti-Semitism in the Dreyfus Affair. They also stifled the anti-democratic, turn-of-the-century anthroposociology 
of George Vacher de Lapouge. After this point, race classifiers rarely cited new work by academic sociologists such as Lapouge or William Ripley of Boston. ${ }^{120}$

Several factors nourished anthropology’s liberalism, including a general mid-century cultural shift from Romantic nationalism to positivist rationalism. Crucially, science’s ideology of rationalist progress made it a natural ally of progressive politicians. As I have argued elsewhere, anthropological institutionalisation therefore thrived in countries such as France and Germany, where progressives powerfully opposed the anti-modernist, anti-science Catholic Church. ${ }^{121}$ Virchow was even able to find common cause with Bismarck against Catholic power, coining the term Kulturkampf for this campaign. When French and Russian conservatives organised ethnographic research programmes that emphasised culture over natural scientific race, they were marginalised as insufficiently scientific. ${ }^{122}$ The rulers of the multi-ethnic Russian, Habsburg, French and British states meanwhile had pragmatic reasons to support cosmopolitan liberal national narratives that welcomed cultural (and racial) diversity. $^{123}$

Overseas colonialism was a second important political factor that weakened race classification of Europeans and its disciplinary coalition. By the early twentieth century, British, Dutch and American ethnologists and anthropologists focused on studying 'native habits and beliefs' and on convincing government and universities that they could aid colonial administration. ${ }^{124}$ This reinforced the 'internal' factor of increasingly influential evolutionary theories. Evolutionists or transformists came to dominate Anglophone and Francophone anthropology by the end of the nineteenth century. Darwinism was certainly politicised. It made humans part of nature. The evolutionary racial hierarchy of 'anthropoid ancestors', 'savage tribes' and modern civilised Westerners was used to legitimise colonialism. ${ }^{125}$ Historians who examine the roots 
of current anthropology, such as Alice Conklin, therefore contrast evolution-centred race anthropology with the new, more genuine respect for 'human cultural diversity' in Marcel Mauss and Bronisław Malinowski’s early twentieth-century cultural anthropology. ${ }^{126}$ Both focused on Europe's overseas colonies. The dehumanisation and 'hypernationalistic context' of colonisation has also been blamed for the brutal racism that percolated into interwar raciology of Europeans. ${ }^{127}$ Whereas scientific classifiers previously studied European races in order to understand national distinctiveness, Nordic supremacists now ranked them within a global evolutionary race hierarchy.

I nevertheless argue that on balance, evolution weakened race anthropology of Europeans. It shifted scientific interest away from the fixed ethnic skull ‘types' of European craniology and towards culture. ${ }^{128}$ Literature on late nineteenth-century evolutionists and transformists shows that they used a combined process of biological and cultural evolution to explain the universal colonial hierarchy, from blond to black. ${ }^{129}$ They were therefore far less fixated on physical race than were the fixist classifiers of Europeans. ${ }^{130}$ For Anglophones especially, focusing on evolution foregrounded research on supposedly backward colonial colour races.

In 1880s Paris, Gabriel de Mortillet's radical left-wing materialist transformists, whom race classifiers hardly cited, wrested control of Broca's Ecole d'Anthropologie from highly-cited liberal fixist classifiers. ${ }^{131}$ Scandalising the fixists, the materialists founded Europe's first 'sociology' chair at the Ecole in 1885, ten years before Durkheim's Bordeaux chair. Durkheimians, who preferred social to biological explanations, reversed this interdisciplinary encroachment by about 1900, transforming mainstream French anthropology into a kind of colonial sociology. By the 1920s, the French meaning of ethnology had shifted from race to 
culture. ${ }^{132}$ Five of the original six Ecole chairs were unambiguously biological, but by 1920, only three of ten were. ${ }^{133}$

\section{Raciology}

After its fin-de-siècle crisis, eclectic scientific race classification revived once more as interwar craniological raciology (Rassenkunde) and its sister science, serology (blood-group anthropology), which the Polish doctor Ludwik Hirszfeld established in 1915. As I have shown elsewhere, there was an international shift from the older positivist literature towards a newer raciological bibliography in the early 1920s. ${ }^{134}$ Raciology focused on race psychology, European races, cultural-physical links, evolutionary hierarchies and, especially in Germany, the superior Teutonic Nordic blond.

Again, multiple scientific and external political causes interacted in this resurrection. Within science, race classifiers remained very attached to racial nations and the coalitions of disciplines required to study them. Physical anthropologists, therefore, never quite realised their positivist objective of decisively detaching races from ethnicity and classifying them by observed physical traits alone. Broca defended 'legitimate and necessary' ethnological histories of races such as France's Celts. ${ }^{135}$ These maintained 'important' physical differences in their statistical ensembles over generations. Positivist anthropologists were nationalists, researching national races and promoting national scientific prestige (including through large skull collections). ${ }^{136}$ Ethnic groups were politically vital symbolic intermediaries between nation and race and made craniologists central to interdisciplinary race classification alliances. In 1885 therefore, the President of the British Anthropological Society identified 'language, social customs, traditions, religious beliefs, and... intellectual and moral attitudes' as useful auxiliaries to 'anatomical' race classification traits. ${ }^{137}$ Into the 1900 s, especially among 
Anglophones, many scientists still used ethno-linguistic categories and terminology and accepted philology-based Aryan race theories. ${ }^{138}$ In 1920, the Swiss anthropologist Eugène Pittard still expected physical similarities among Romanian speakers in different countries. ${ }^{139}$

I argue that anthropologists therefore often tried to preserve interdisciplinary institutional arrangements, especially in Anglophone countries. ${ }^{140}$ The Darwinism of Britain's Anthropological Institute and of Franz Boas's 'four fields' organisation of anthropology departments in American universities delayed disciplinary fission. It linked biological and cultural 'race' diversity through parallel processes of evolution. ${ }^{141}$ British anthropologists tried with variable success to preserve this interdisciplinary 'happy family' in the organisation of international anthropological congresses. ${ }^{142}$

Several theories were proposed to defend the useful ethno-racial connection. Anthropologists widely assumed that brain shape determined psychology and, ultimately, culture. ${ }^{143}$ Several scholars, including the leading Darwinist zoologist Ernst Haeckel in Germany, argued that languages arose separately among mentally unequal, speechless proto-human varieties. ${ }^{144}$ Researchers commonly assumed that cultural barriers blocked racial interbreeding. ${ }^{145}$ Theorists from Renan to Günther in the 1920s used 'linguistic races' such as the Aryans and Semites to surreptitiously re-link race and nation. ${ }^{146}$ Anthropologists such as Arthur Keith in Britain and several eastern Europeans saw nationalism, cultural assimilation, geographical adaptation and war as natural forces. ${ }^{147}$ These forces 'immediately sets out to repair' the unnatural 'mischief' caused when civilisation mixed races and dissolved their 'physical cohesion'.

However, the most important new scientific idea for raciology and serology was their combination of a reinterpreted Darwinism with the 1900 rediscovery of Gregor Mendel's 
genetic theory. Classifiers represented blood groups and raciology’s tenuous, statisticallyreconstructed types as 'irreducible', genetically inherited units, 'like the simple bodies in a chemical composition'. ${ }^{148}$ Raciologists therefore made Europe a closed system of five to twelve races, most of which had been devised by the Franco-Russian anthropologist Joseph Deniker in the 1890s. ${ }^{149}$ Earlier anthropologists had concentrated on identifying races from the geographical overlap of two or three traits, such as skull shape, stature and hair colour. Raciological schools by contrast proposed competing procedures to 'diagnose' the racial identity of individuals, based on statistically analysing a strictly defined set of about a half dozen measures. As before, these traits were chosen for supposedly resisting environmental influence. ${ }^{150}$

Raciologists used a technique pioneered in the 1880s-1890s to preserve the link between races and nations. ${ }^{151}$ They statistically associated 'different frequencies' of race elements in nations with historical immigrations and attributed each nation's 'particular racial character' to the most numerous local race. ${ }^{152}$ Hitler and other fascist race theorists agreed that certain 'superior and creative' 'racial components', such as the Nordic in Germany, dictated the 'entire ethnic and cultural complex’ of racially mixed modern nations. ${ }^{153}$

Turning to factors in the broader culture, historians of anthropology widely recognise that a cultural wave of racist, 'völkisch' or neo-Romantic hypernationalism also stimulated the revival of eclectic race classification. ${ }^{154}$ This wave swept Europe from the 1890s, combining militarist authoritarianism, xenophobia, anti-Semitism and anti-modern conservatism. Whereas nineteenth-century race classification centred quite tightly on north-west European physical anthropology, the hothouse of interwar political race classification was multipolar in both its interdisciplinarity and geography. Its intricate science-politics ecology embraced 
popular race theorising, eugenics and extreme-right politics, as well as scholarly disciplines. United by a neo-Romantic agenda and outlook, raciologists cooperated within a politically emotive and holistic new transdisciplinary scientific race research programme. They outflanked liberal opponents, who were isolated behind disciplinary boundaries and apolitical self-restraint. ${ }^{155}$ Anthropology contributed a key neo-Romantic motif, the race hierarchy topped by the Nordic. A second emblem, the prehistoric, superior, Aryan ethno-national ancestor, emerged from linguistics but was heavily reworked by anthropologists. NeoRomantics transformed Aryans into native north European Nordics. This rejected the dominant anthropological representation of them, present since the 1870s, as short dark invaders from Asia.

The 'almost baroque’ dilettantism of raciology's interdisciplinary alliance embraced fields from theology to musicology and genealogy. Raciology was itself one of several overlapping alliances in the interdisciplinary networks of neo-Romantic race science in Germany and elsewhere. Raciologists, demographers, 'geneticists, psychiatrists and social hygienists' cooperated within eugenics. ${ }^{156}$ A German humanities alliance, centred on prehistory and folklore, concentrated more on Germanic culture than Nordic race. It received particularly lavish Nazi largesse. ${ }^{157}$ Neo-Romantic serologists, who ostracised Jewish colleagues, forged strong links with colleagues in folklore and demography. ${ }^{158}$

Neo-Romantic raciology reengaged with a new crop of extremely popular Nordic-Aryan supremacist polemicists such as Lothrop Stoddard and Madison Grant in America, and, in Germany, Ludwig Woltmann and Houston Stewart Chamberlain. Chamberlain was the British son-in-law of the composer Richard Wagner. These race writers were the successors of the philosophical ethnologists whom professionalising nineteenth-century anthropology had 
delegitimised. From the late nineteenth century, the Nordic supremacists challenged professional anthropologists' role as society's foremost race experts. They harshly criticised the endless 'detailed measurements' and methodological and terminological disputes of 'ever more complicated, technical and sophisticated' liberal, positivist craniology. ${ }^{159}$ These, they thought, 'swallowed up' the 'important social and political questions' that anthropology should have solved. Neo-Romantic race theorists attacked craniology's 'sorry role', 'changing hypotheses', ‘higgledy-piggledy’ ‘confusion' and ‘unbelievable lack of judgement' in asserting race equality. ${ }^{160}$ Chamberlain disparaged 'hidden' scientific causes and 'so-called' results, declaring that 'practical, hands-on men' such as himself required only 'what lies clearly before our eyes'. One belonged to a race simply because one 'feels it daily'. ${ }^{161}$

As World War One mobilised German anthropology for nationalist duty, however, a new generation of sympathetic anthropologists began selectively referencing popular racist theorists and vice versa. ${ }^{162}$ Anti-intellectual, 'mystical' and militant popular interwar fascist race ideologues such as Alfred Rosenberg in Germany and Julius Evola in Italy drew enthusiastically on contemporary scientific raciology. German raciology in turn increasingly aligned itself with Hitler's nationalist racist state. ${ }^{163}$

Raciology emerged as part of a discipline-by-discipline and country-by-country struggle between liberal positivists and neo-Romantic nationalists for control of academic scholarship. ${ }^{164}$ From the 1890s, hypernationalist völkisch German conservatives captured archaeology and folklore research. ${ }^{165}$ While interwar German folklorists (Volkskundler) aimed to access the Germanic Volksgeist (folk spirit), archaeologists sought to enlarge cultural-racial 'ancient Germanic territory'. ${ }^{166}$ Incomplete institutionalisation helped the exceptionally popular Kossinna to return prehistoric archaeology to its highly politicised pre-1850s Romantic 
tradition. ${ }^{167}$ This automatically associated ancient artefacts with the 'sharply delineated' languages and races of supposed ancestors.

Two new types of applied race scholarship created vital interdisciplinary bridges, helping scientific raciology to assimilate neo-Romantic culture and right-wing politics. First, the racecentred, nationalistic socio-biological engineering programme of eugenics rapidly became influential in 1900-10. ${ }^{168}$ As well as advocating laws to sterilise or euthanase supposed biological inferiors, it promoted and helped politicise raciology, even in Bolshevik Russia. ${ }^{169}$ It also shared personnel, ideals, medical training and Mendelian genetics with raciology. ${ }^{170}$

Second, what interdisciplinarity scholars describe as 'border interdisciplinarity', or chimeras of existing disciplines such as biochemistry or geophysics, proliferated on the right-wing fringes of race anthropology. ${ }^{171}$ From the 1870s, the Italian criminal anthropologist Cesare Lombroso represented delinquents as 'evolutionary throwbacks'. ${ }^{172}$ Haeckel interpreted evolution as racial struggle and linked individual worth to race. ${ }^{173}$ Some chimeras used the 'anthropo' prefix to reference race biology. Though fin-de-siècle anthroposociology was supressed, for example, it reintroduced superior Nordic Aryans, Darwinism, anti-Semitism and eugenic worries about miscegenation into scientific anthropology. Its statistical comparisons of social class and race became an integral raciological technique. German territorial expansionists enthusiastically welcomed the biological 1889 Lebensraum (living-space) concept of Friedrich Ratzel's anthropogeography.

As ever, centrifugal forces strained interdisciplinary alliances. Disciplines emerged to study entirely new racial characteristics, including blood-group, IQ and Nicola Pende’s supposedly Mendelian concept of constitutional type, diagnosed from physiology and bio-chemistry. ${ }^{174}$ 
The usefulness and convenience of blood testing made serology popular. ${ }^{175}$ However, my research finds that raciologists and serologists had different training, established separate institutions, collected evidence independently and were very often reluctant partners. ${ }^{176}$ They claimed the priority of their own race systems and ignored one another's. My data and other evidence suggest that raciologists almost never cited serologists. ${ }^{177}$ They feared competition from its distinct classification system, which contrasted superior ‘European’ type A blood with the type B of 'Africa and Asia'. ${ }^{178}$ However, the right-wing racist political agenda was a powerful glue. Interdisciplinary researchers therefore attempted to link raciological and serological races from the start. They suggested the former were genetically inherited, and associated serology with anthropology's august tradition and intricate techniques. ${ }^{179}$

The neo-Romantic science-politics alliance was also full of tensions. Because eugenists aimed to improve national bloodstock by eliminating non-racially defined groups such as alcoholics and criminals, they often treated nations rather than immutable anthropological types as their basic 'races'. ${ }^{180}$ In Germany, anthropology moved to the nationalist right long after archaeology. ${ }^{181}$ Even fascist anthropologists resisted full immersion in Günther’s populist raciological propaganda-science. ${ }^{182}$ Eugen Fischer, interwar German anthropology’s 'recognised Führer' and an inveterate Nordic supremacist, was accused of merely opportunistic support for fascism and of prioritising scientific evidence over politically important conclusions. ${ }^{183}$ Egon von Eickstedt, the Third Reich's leading scientific race classifier, applied to join the Nazi party in 1933 but avoided its most incriminating projects and successfully rehabilitated his career after $1945 .{ }^{184}$ Bibliographical data suggests that interwar classifiers cited dry scientific periodicals far more often than they did eugenic, Nordicist and völkisch racist periodicals. ${ }^{185}$ 
Just as the strong disciplinary pole of nineteenth century anthropology gave way to interwar disciplinary multipolarity, so interwar geographical diversity replaced race anthropology’s old Franco-German core. Scandinavia and the US were global centres for eugenics, for example, but weak in raciology. ${ }^{186}$ Analyses of citation, institutions and attendance at international conferences, particularly, highlight an east-west division in raciology. ${ }^{187}$ Whereas ethnology and anthropology had flourished in most scientifically advanced countries, raciology thrived, on the whole, only to the east of the Rhine. Methodologically incompatible schools of raciology around Europe competed with post-racial Western anthropology, and also with one other. Concrete causes and historical contingency created a complex geography, combining the multiple elements of neo-Romantic politics and scholarship in different ways in different countries. Poland’s Lwów School, for example, shared significant elements of nationalism and elitist Nordic supremacism and certain basic ground-rules of raciology with Germany. ${ }^{188}$ However it had highly idiosyncratic technical elements, limited anti-Semitism, and little neoRomantic pessimism or mysticism. The ideological core of Lwów’s transdiscipline was less neo-Romanticism than it was the complex statistical apparatus of the school's leader, Jan Czekanowski. This included 'historically the first method of cluster analysis'.189 Czekanowski's students used his techniques to investigate 'ethnographic, linguistic, experimental psychological and even economic questions'. ${ }^{190}$ There was also spatial diversity within countries. Nazi raciology influenced raciology, eugenics and serology in Cluj much more than in other Romanian centres, for example. ${ }^{191}$

Geographical multipolarity made interdisciplinary interactions even more complex and often paradoxical. For example, German archaeology was one of the first disciplines captured by völkisch nationalism. As a result, the leaders of Poland’s Poznań School of artefact archaeology and Kossinna's other central European Slav students were trained in his ultra-nationalistic 
methods. ${ }^{192}$ Using these against him, they remained locked in close combat with Germany. Poznań's interdisciplinary collaborators in Lwów raciology were also Polish nationalists, but resisted the extreme right-wing politics of their German peers. This was in part because they had trained with an older liberal generation of German anthropologists. The cutting edge statistical method at the centre of Lwów’s ambitious interdisciplinary alliance produced a highly controversial reformulation of raciology. ${ }^{193}$ This in turn hindered adversarial engagement with Germany, for example by making ancient Slav and Teutonic skulls indistinguishable. The Lwów School’s nationalist claim that Slavs were Nordic, though accepting Germany’s Nordic supremacist race hierarchy, may therefore ultimately have encouraged greater innovation and independence than in Poznań.

\section{Conclusion}

Believing race to be the scientific key to understanding modern society and history, successive nineteenth and early twentieth-century coalitions of ethnologists, anthropologists and raciologists aimed to make it the central organising principle of the human sciences. In this ambition, race classification of Europeans resembled later transdisciplinary projects such as Marxism, structuralism and the post-1970 movement that has adopted the transdisciplinary label. To associate biological race types with cultural nations, classifiers defined and identified races by assemblages of physical, psychological and cultural traits. These could include skull shape, aptitude for conquest or civilisation, grammatical structures or prehistoric pottery decorations. This transdisciplinary project shaped the history of anthropology and of social science as a whole. Although classification software ran on the hardware of anthropology, it was the discipline's core issue for about a century. The hardware, including the 
transdisciplinary alliances of physical anthropology with almost all the emerging social sciences, was therefore often configured to support it.

This project catered to public demand for politically useful nationalist, liberal or authoritarian race theories. Classifiers gave races histories and geographies with implicit meanings for the politics of international relations, modern progress and social class. These political narratives demanded a particular model of race. It should, for example, be fixed in descent, occurring in pure form in ancient tribes and identifiable through convenient race markers such as dolichocephaly-brachycephaly or the A and B blood groups. For a century, from Romantic period ethnology to interwar raciology, classifiers doggedly defended this conservative model. They legitimised innovations, for example, by claiming continuity with established authorities. The politically useful race model therefore survived broad cultural oscillations between Romanticism and liberalism. It also adapted to momentous scientific disruptions such as evolutionary theory and a gradual shift from racially homogeneous ethnic groups to raciallymixed individuals. Successive generations, ignorant of repeated earlier failures convincingly to link biology with ethnic nation, independently reinvented politically useful ideas. Interwar serology, for example, unhesitatingly attempted the same politically tempting scientific justification of ‘folk-wisdom’ as ethnology had done a century before. ${ }^{194}$ It analysed 'the ethnoanthropological composition of present populations' to theorise race migrations, ancient racecrossings, 'origin and relationships'. ${ }^{195}$

This politically relevant research programme generated public and official support for the institutionalisation of race classification's component disciplines. However, the resulting professionalisation and independence of disciplines undermined the politicised scientific agendas and interdisciplinary collaborations that had won political support. Just like the 
interwar scholars of evolution whom Amanda Rees describes, 1860s anthropologists and interwar raciologists all wanted to collaborate with other disciplines but insisted that these partners take a subordinate role. ${ }^{196}$ Philologists, archaeologists and finally physical and cultural anthropologists therefore lost interest in eclectic race classification. They developed disciplinespecific research topics, and methods that produced incompatible results. Even physical anthropology, the core discipline of race classification, progressively purged itself of cultural and historical interests. The explicitly apolitical positivist scientific ideology of professional science constrained political engagement. Classifiers had to accept research evidence that systematically undermined the scholarly basis of race concepts. They also disassociated themselves from the popular race writing that connected scientific and political spheres.

Multiple factors repeatedly undermined the methods and concepts of classification and fragmented its alliances. ${ }^{197}$ They include scientific professionalisation and apoliticism, geopolitical stresses, ideological shifts, changing scientific assumptions and evidence, and the centrifugal tensions of a spatially expanding international community. For a century, however, politically inspired classifiers repeatedly seized upon new approaches to assemble successive ethnological, anthropological and raciological alliances of 'disciplines'. Analysis of classical texts, antiquarian etymology, comparative philology, craniology, artefact archaeology, quantification, Mendelian genetics, biometric statistics and serology were all therefore used in turn to define races or trace their history. The partial and piecemeal nature of professionalisation helped preserve politically vital elements of classification.

Race anthropology, however, ultimately lost this struggle to reconcile science and politics. After the project's great turn-of-the-century crisis, rival methodologies proliferated, including competing interwar raciologies. A faultline opened up at the Rhine. To the west, apolitical post- 
racial anthropology gradually divided into separate physical and cultural professions, neither focused on race. To the east, nationalist interwar raciology and serology adopted new scientific underpinnings and renewed alliances with cultural disciplines. However, they required political links with extreme right-wing, nationalist, neo-Romantic race ideologues to thrive. The new transdisciplinary coalitions grew directly from a neo-Romantic renaissance of völkisch nationalism and racist political theory. However, the usual combination of 'internal' scientific and 'external' political reasons led by the 1950s to the abandonment of race classification of Europeans. It was discredited by association with Nazism and undermined by a new synthesis of genetics and evolution, which rejected race as a useful biological concept.

Disciplines ultimately prevailed over transdisciplines in the organisation of scholarship and the categorisation of society into a constellation of realms such as politics, the economy and culture. However, race classification demonstrates that this disciplinary system is a product of historical contingency, challenged by inter- and transdisciplinary experiments from the very start. Disciplines may themselves be superseded by alternative organisations of knowledge in the future. 
* School of Social, Historical and Literary Studies, University of Portsmouth, Milldam, Burnaby Road, Portsmouth, PO1 3AS, U.K. Email: rychumac@yahoo.com.

\footnotetext{
${ }^{1}$ Walter Rüegg, 'Themes', in W. Rüegg (ed.), A history of the university in Europe: Volume 3, universities in the nineteenth and early twentieth centuries (1800-1945) (Vol. 3), Cambridge: Cambridge University Press, 2004, pp. 3-31: 9; Christophe Charle, 'Patterns', in Rüegg (ed.), university in Europe: 59; Peter Wagner, The twentieth century - the century of the social sciences? Paris: ISSC, 1999, pp. 16-41: 19.

${ }^{2}$ Wagner, twentieth century.

${ }^{3}$ William Wilde, 'The Early Races of Mankind in Ireland', The Irish Builder (1874) Sept. 1, Sept 15 \& Oct 1: 245-46, 258-59 \& 273-74, 245; J.A.N. Périer, Alphonse Bertillon and Gustave Lagneau, 'Notice-questionnaire sur l'anthropologie de la France', Bulletins de la Société d'Anthropologie de Paris (1861) 2: pp. 327-420, 32728 \& 338.

${ }^{4}$ Chris Manias, Race, Science and the Nation: Reconstructing the Ancient Past in Britain, France and Germany, 1800-1914, New York: Routledge, 2013, pp. 10-11; Carole Reynaud-Paligot, De l'identité nationale: Science, race et politique en Europe et aux Etats-Unis XIXe-XXe siècle, Paris: Presses Universitaires de France, 2011, p. 7 ; Richard McMahon, The Races of Europe: Construction of national identities in the social sciences 18391939, Houndsmills: Palgrave, 2016.

${ }^{5}$ Roderick J. Lawrence, ‘Advances in transdisciplinarity: Epistemologies, methodologies and processes’, Futures (2015) 65, pp. 1-9: 2; Jay Hillel Bernstein, 'Transdisciplinarity: A review of its origins, development, and current issues', Journal of Research Practice (2015) 11(1), pp. 1-20: 5.

${ }^{6}$ B.C. Choi and A.W. Pak, 'Multidisciplinarity, interdisciplinarity and transdisciplinarity in health research, services, education and policy: 1. Definitions, objectives, and evidence of effectiveness', Clinical and Investigative Medicine (2006) 29(6), pp. 351-64: 355; P. Osborne, Problematizing disciplinarity, transdisciplinary problematics. Theory, culture \& society (2015) vol. 32 no. 5-6, pp. 3-35: 14-19; Julie Thompson Klein, 'Discourses of transdisciplinarity: Looking back to the future', Futures (2015) 63, pp. 68-74: 69.

${ }^{7}$ J.T.Klein, Interdisciplinarity: History, theory, and practice, Detroit: Wayne State University Press, 1990, p. 23; Osborne, 'Problematizing disciplinarity', p. 5.

${ }^{8}$ Osborne, 'Problematizing disciplinarity', pp. 4-5; J. Heilbron and Y. Gingras, 'La résilience des disciplines', Actes de la recherche en sciences sociales (2016) 5, pp. 4-9: 5.

${ }^{9}$ Jon Agar, Science in the 20th Century and Beyond, Cambridge: Polity, 2012., pp. 170-72.

${ }^{10}$ Osborne, 'Problematizing disciplinarity', p. 3; Rudolf Stichweh, 'The sociology of scientific disciplines: On the genesis and stability of the disciplinary structure of modern science', Science in Context (1992) 5(1), pp. 315: 6 .

${ }^{11}$ J. Heilbron, N. Guilhot and L. Jeanpierre, 'Toward a transnational history of the social sciences', Journal of the History of the Behavioral Sciences (2008) 44(2), pp.146-160: 149-50.

${ }^{12}$ W.J. Heilbron, 'A regime of disciplines: Toward a historical sociology of disciplinary knowledge', in Camic, C. and Joas, H. (eds.), The dialogical turn: New roles for sociology in the postdisciplinary age, Lanham: Rowman \& Littlefield, 2004, pp. 23-42: 25, 31-32; R. Valenza, Literature, language, and the rise of the intellectual disciplines in Britain, 1680-1820, Cambridge: Cambridge University Press, 2009, p. 5; Heilbron and Gingras, 'résilience', p. 5, 8; Charle, 'Patterns', p. 59; Peter Wagner, A history and theory of the social sciences: not all that is solid melts into air, Thousand Oaks: Sage, 2001, pp. 1-2; Osborne, 'Problematizing disciplinarity', p. 3.

13 J.M. Chapoulie, 'Un cadre d'analyse pour l'histoire des sciences sociales', Revue d'histoire des sciences humaines (2005) 2, pp. 99-126: 105-8; Heilbron and Gingras, 'résilience’, p. 8.

${ }^{14}$ Race, Science and the Nation: Reconstructing the Ancient Past in Britain, France and Germany, 1800-1914, New York: Routledge 2013, pp.5-6.

${ }^{15}$ Heilbron, “A regime of disciplines”, pp. 31-32.

${ }^{16}$ Peter Bowler, The invention of progress: the Victorians and the past, Oxford: Blackwell, 1989, p. viii.
} 
${ }^{17}$ E. Messer-Davidow, D.R. Shumway and D. Sylvan , 'Introduction: Disciplinary Ways of Knowing', in E. Messer-Davidow, D.R. Shumway and D. Sylvan (Eds.), Knowledges: Historical and critical studies in disciplinarity, Charlottesville: University of Virginia Press, 1993, pp. 1-21: 4. The term is Foucault's but I do not adopt the full suite of implications that attend his perspective.

${ }^{18}$ Laurent Mucchielli, 'Durkheimiens dans le contexte " fin de siècle " (1885-1902)', 1997, http://laurent.mucchielli.free.fr/raciologie.htm, accessed 25-5-2014.

${ }^{19}$ Messer-Davidow et al., 'Introduction', p. 4.

${ }^{20}$ R. Adler-Nissen and K. Kropp, 'A Sociology of Knowledge Approach to European Integration: Four Analytical Principles', Journal of European Integration (2015) Vol. 37, No. 2, pp. 155-173: 156 \& 160-65.

${ }^{21}$ Lawrence, 'Advances’, p. 4.

${ }^{22}$ Osborne, 'Problematizing disciplinarity', pp. 10-11. ${ }^{23}$ Cited in Herbert H. Odom, 'Generalizations on Race in Nineteenth-Century Physical Anthropology’, Isis (1967) 58(1), pp. 4-18: 9.

${ }^{24}$ J. Gould Avery, 'Civilisation; with Especial Reference to the So-Called Celtic Inhabitants of Ireland', Journal of the Anthropological Society of London (1869), 7, pp. ccxxi-ccxxxvii: ccxxiv.

${ }^{25}$ Matti Bunzl and H. Glenn Penny, 'Introduction: Rethinking German Anthropology, Colonialism, and Race', in H. Glenn Penny and Matti Bunzl, (eds.), Worldly Provincialism: German Anthropology in the Age of Empire, Ann Arbour: University of Michigan Press, 2003, pp. 1-30: 5.

${ }^{26}$ Manias, Race, p. 4-5. Reynaud-Paligot, l'identité nationale, p. 9.

${ }^{27}$ McMahon, Races of Europe, pp. 49-50.

${ }^{28}$ Messer-Davidow et al., 'Introduction', p. 7.

${ }^{29}$ McMahon, Races of Europe, pp. 20-23.

${ }^{30}$ George W. Stocking Jr., The Ethnographers’ Magic and Other Essays in the History of Anthropology, Madison: University of Wisconsin Press, 1992, p. 350.

${ }^{31}$ Hannah Franziska Augstein, James Cowles Prichard's anthropology: remaking the science of man in early nineteenth-century Britain, Amsterdam: Rodopi, 1999, p. 231. Martin S. Staum, Labeling People: French Scholars on Society, Race, and Empire, 1815-1848. Montreal: McGill-Queen's University Press, 2003, pp: 13233; Claude Blanckaert, 'On the Origins if French Ethnology: William Edwards and the Doctrine of Race', in George W. Stocking Jr. (ed.), Bodies, Bones, Behaviour: Essays on Biological Anthropology, Madison \& London: University of Wisconsin Press, 1988: pp. 18-55: 18-19.

32 Blanckaert, 'Edwards', pp. 38-39 \& 46.

${ }^{33}$ Ibid, pp. 27-28; McMahon, Races of Europe, p. 25.

${ }^{34}$ Ibid, p. 18.

${ }^{35}$ William Edwards, 'Des Caractères Physiologiques des Races Humaines considérés dans leur rapports avec l'histoire: Lettre à M. Amédée Thierry, auteur de l'histoire des Gaulois', Mémoires da la Société Ethnologique (1841 [1829]) 1, pp. 1-108: 2; Blanckaert, 'Edwards', p. 19.

${ }^{36}$ Nélia Dias, Le Musée d'Ethnographie du Trocadero (1878-1908): Anthropologie et Muséologie en France, Paris: Centre National de la Recherche Scientifique, 1991, p. 19.

${ }^{37}$ Benoit Massin, 'From Virchow to Fischer: Physical Anthropology and "Modern Race Theories" in

Wilhelmine Germany’, in George W. Stocking Jr. (ed.), Volksgeist as Method and Ethic: Essays on Boasian Ethnography and the German Anthropological Tradition, Madison: University of Wisconsin Press, 1996, pp. 79-154: 120-21.

${ }^{38}$ Blanckaert, 'Edwards’, p. 26; Edwards, ‘Caractères Physiologiques’, pp. 82-83.

${ }^{39}$ Stephen Jay Gould, The Mismeasure of Man, New York: Norton, 1981, p. 25; Blanckaert, 'Edwards’, p. 38.

${ }^{40}$ Edwards, 'Caractères Physiologiques', pp. 37-39.

${ }^{41}$ Stocking, Ethnographers' Magic, p. 350.

${ }^{42}$ George W. Stocking Jr., Victorian Anthropology, New York: Free Press, 1991, p. 244; Claude Blanckaert, 'L’indice céphalique et l'ethnogénie européenne: A. Retzius, P. Broca, F. Pruner-Bey (1840-1870)', Bulletins et Mémoires de la Société d'Anthropologie de Paris (1989) n.s. 1(3-4), pp. 165-202: 182; Edwards, 'Caractères Physiologiques', pp. 82-83.

43 'Edwards', pp. 41 \& 44.

44 Jennifer Michael Hecht, The End of the Soul: Scientific Modernity, Atheism, and Anthropology in France, New York: Columbia University Press, 2003, p. 56.

45 James Hunt, 'The President's Address', Journal of the Anthropological Society of London (1864) 2, pp. lxxxxcv: xcii; Stocking, Victorian Anthropology, p. xcii.

${ }^{46}$ Hunt, 'President's Address', pp. 247-48

${ }^{47}$ Ibid, p. 46; McMahon, Races of Europe, p. 25.

${ }^{48}$ E.g. John Thurnham, 'Sur les deux principales formes des anciens crânes Bretons et gaulois’, Bulletins de la Société d'Anthropologie de Paris (1864) Vol. 5, pp. 395-421: 402.

${ }^{49}$ William R. Wilde, The Beauties of the Boyne and its Tributary, the Blackwater, Dublin: James McGlashan, 1849, p. 230. 
${ }^{50}$ Nélia Dias, 'Séries de crânes et armée de squelettes: Les collections anthropologiques en France dans la seconde moitié du XIXe siècle’, Bulletins et Mémoires de la Société d'Anthropologie de Paris (1989) n.s. 1(34), pp. 203-30: 205-25.

${ }^{51}$ Blanckaert, 'L’indice', pp. 166-67; Gustaf Retzius, 1909, ‘The So-Called North European Race of Mankind. A Review of, and Views on, the Development of Some Anthropological Questions', Journal of the Royal Anthropological Institute of Great Britain and Ireland, 39(2), pp. 277-313: 283.

52 Stocking, Victorian Anthropology, p. 248; H. Vallois, 'Zum hundertjahrigen Bestehen der Societe d'Anthopologie de Paris (1859-1959)', Anthropologische Anzeiger (1959) 23(1), pp. 75-81: 77.

${ }^{53}$ Hunt, 'President's Address', p. xcii; Wilde, ‘Early Races’, p. 245; Maria Sophia Quine, 'Making Italians: Aryanism and Anthropology in Italy during the Risorgimento’, In M. Turda (Ed.), Crafting humans: from Genesis to eugenics and beyond, Goettingen: V\&R Unipress, 2013., pp. 127-152: 132.

${ }^{54}$ Stocking, Victorian Anthropology, p. 248; Mucchielli, ‘durkheimiens’, p. 2; Dias, Musée, p. 22.

${ }^{55}$ William Z. Ripley, A Selected Bibliography of the Anthropology and Ethnology of Europe, Boston: Public Library, 1899, pp. vii-viii.

${ }^{56}$ Stocking, Victorian Anthropology, p. 249; Mucchielli, ‘durkheimiens’, p. 2.

${ }^{57}$ Massin, ‘Wilhelmine Germany’, p. 126; Egon Freiherr von Eickstedt, Die Forschung am Menschen: Teil 1: Geschichte und Methoden der Anthropologie, Stuttgart: Ferdinand Enke, 1940: 156; E.B. Taylor, 'President's Address', Journal of the Anthropological Institute of Great Britain and Ireland (1880) 9, pp. 443-458: 448.

${ }^{58}$ G.G.MacCurdy, 'Extent of Instruction in Anthropology in Europe and the United States', Science (1899) 10, pp. 910-17: 915-16; Iordache Făcăoaru, 'Antropologia în ţările de cultură', Buletinul Eugenic şi Biopolitic (1938) 9(7-8), pp. 207-18: 212 \& 216.

${ }^{59}$ Stocking, Victorian Anthropology, pp. 249-54.

${ }^{60}$ Robert Proctor, 'From Anthropologie to Rassenkunde in the German Anthropological Tradition', in George W. Stocking Jr. (ed.), Bodies, Bones, Behaviour: Essays on Biological Anthropology, Madison: University of Wisconsin Press, 1988, pp. 138-79: 141.

${ }^{61}$ John V. Day, 'Aryanism', in Frank Spencer (ed.), History of Physical Anthropology: An Encyclopedia: Vol. 1, New York: Garland, 1997, pp. 109-12: 110; Proctor, ‘Tradition’, p. 141; Vallois, ‘hundertjahrigen’, p. 78.

${ }^{62}$ Andrew D. Evans, Anthropology at war: World War I and the science of race in Germany, Chicago: University of Chicago Press, 2010, p. 27.

${ }^{63}$ Frank Spencer, 'Broca, Paul (Pierre) (1824-1880)', in F. Spencer (ed.), History of Physical Anthropology: An Encyclopedia, New York: Garland, 1997, pp. 221-22: 221.

${ }^{64}$ Vallois, 'hundertjahrigen', p. 78.

${ }^{65}$ Louis-Achille Bonté, 'Sur les Celtes', Bulletins de la Société d’Anthropologie de Paris (1864) 5, pp. 624-33: 629.

${ }^{66}$ Hildegard L.C. Tristram, ‘Celtic Linguistic Taxonomy in the Nineteenth Century’, in Terrence Brown (ed.), Celticism, Amsterdam: Rodopi, 1996, pp. 35-60: 45; Julien Girard de Raille, 'De la race Celtique', Bulletins de la Société d'Anthropologie de Paris (1864) 5, pp. 550-56: 552.

${ }^{67}$ Blanckaert, 'L’indice', pp. 172-3 \& 180-82; Andrea Orsucci, 'Ariani, indogermani, stirpi mediterranee: aspetti del dibattito sulle razze europee (1870-1914)’, Cromohs (1998) 3, www.unifi.it/riviste/cromohs, p. 9. 68 J.A.N. Périer, 'Que les vrais Celtes sont les vrais Galois', Bulletins de la Société d'Anthropologie de Paris (1864) 5, pp. 590-624: 621.

${ }^{69}$ Bonté, 'Celtes', pp. 630-31.

${ }^{70}$ H. von Hölder, Zusammenstellung der in Württemberg vorkommenden Schädelformen, Stuttgart:

Schweizerbart, 1876, pp. 6 \& 19; Périer, 'vrais Celtes’, pp. 617.

${ }^{71}$ William Ripley, The Races of Europe: A Sociological Study, London: Kegan Paul, Trench, Trubner \& Co., 1900, p. 125.

72 Franz Pruner-Bey, 'Sur les deux principales formes des anciens crânes bretons et gaulois', Bulletins de la Société d’Anthropologie de Paris (1864) Vol. 5, pp. 405-19: 412-415.

${ }^{73}$ Hölder, Zusammenstellung, p. 18.

74 Pruner-Bey, 'Celtique', pp. 666-68.

75 John L. Myres, 'Presidential Address. Anthropology: National and International', Journal of the Royal Anthropological Institute of Great Britain and Ireland (1930) 60, pp. 17-45: 40; Matthew R. Goodrum, ,The beginnings of human palaeontology: prehistory, craniometry and the 'fossil human races', The British Journal for the History of Science (2016): 49(3), pp. 387-409: 409.

76 Blanckaert, 'L’indice’, pp. 187 \& 189; Girard de Raille, 'race Celtique’, pp. 568-69.

${ }^{77}$ Franz Pruner-Bey, 'Sur la question Celtique’, Bulletins de la Société d’Anthropologie de Paris (1864) 5, pp. 657-79: 664 .

${ }^{78}$ Abel Hovelacque, 'Les Celtes de la linguistique’, Revue d'Anthropologie (1873) 2, pp. 187-99: 499;

Alexandre Bertrand, 'Sur les origines européennes', Bulletins de la Société d'Anthropologie de Paris (1864) 5, pp. 302-18 \& 367-83: 370. 
${ }^{79}$ Périer, ‘vrais Celtes’, pp.620-21.

${ }^{80}$ McMahon, Races of Europe, pp. 50-51.

${ }^{81}$ Ibid, pp. 53.

${ }^{82}$ Karel Sklenáŕ, Archaelogy in Central Europe: The first 500 Years, Leicester: Leiecster University Press, 1983, p. 134.

${ }^{83}$ Vallois, 'hundertjahrigen', pp. 77-79; Claudio Pogliano, L'ossessione della razza: Antropologia e genetica nel xx secolo, Pisa: Edizioni della Normale, 2005, pp. 405 \& 415.

${ }^{84}$ Stocking, Ethnographers' Magic, p. 353.

${ }^{85}$ Sklenář, 500 Years, p. 135-38; Uwe Puschner, 'Die Germanenideologie im Kontext der völkischen

Weltanschauung’, Göttinger Forum für Altertumswissenschaft (2001) 4, p. 93.

${ }^{86}$ John L. Myres, 'Presidential Address: Anthropology, Pure and Applied', Journal of the Royal

Anthropological Institute of Great Britain and Ireland (1931) 61, pp. xxv-xli: xxvi; Juan Comas, Historia y

Bibliografia de los Congresos Internacionales de Ciencias Antropologicas: 1865-1954, Mexico: Universidad Nacional Autonoma de Mexico, 1956, p. 47.

${ }^{87}$ Elizabeth Fee, 'Nineteenth-Century Craniology: The Study of the Female Skull', Bulletin of the History of Medicine (1979) 53(3), pp. 415-33: 419 \& 426-27; Massin, ‘Wilhelmine Germany’, p. 106.

${ }^{88}$ Ripley, The Races, p. 34.

${ }^{89}$ Massin, 'Wilhelmine Germany’, pp. 106 \& 110-11; Retzius, ‘North European Race’, p. 278; Quine, ‘Making Italians', p. 147.

${ }^{90}$ Augustus Henry Keane, Ethnology (2nd revised edition), Cambridge: Cambridge University Press, 1896, p. 151; Pogliano, L’ossessione, p. 395 ; Armand de Quatrefages, Histoire générale des races humaines:

Introduction à l'étude des races humaines, Paris: Hennuyer, 1889, p. 488.

${ }^{91}$ Rudolf Pöch, 'Bericht über die von der Wiener Anthropologischen Gesellschaft in den k. u. k.

Kriegsgefangenenlagern veranlassten Studien’, Mitteilungen der Anthropologischen Gesellschaft Wien (1917) 47, pp. 77-100: 78-79; Dias, 'collections', pp. 221-22.

${ }^{92}$ G.M. Morant, 'Racial Theories and International Relations', Journal of the Royal Anthropological Institute of Great Britain and Ireland (1939) 69(2), pp. 151-62: 157; Pöch, 'Bericht‘, pp. 78-79.

93 'Types fondamentaux et types secondaires en Europe’, Institut International d'Anthropologie: IIe session: Prague 14-21 Septembre 1924, Paris: Nourry, 1926, pp. 145-50: 149.

${ }^{94}$ Hans-Jürgen Lutzhöft, Der Nordische Gedanke in Deutschland 1920-1940, Stuttgart: Klett, 1971, pp. 96 \& 98.

95 Julian Talko-Hryncewicz, 'Słów pare ze stanowiska antropologji w kwestii pochodzenia Slowian', Wisła (1902) 16, pp. 754-61: 761.

${ }^{96}$ Kollmann, Julius, 'Beitrag zu einer Kraniologie der europäischen Völker', Archiv für Anthropologie (1880)

13, pp. 79-122 \& Tafeln II-IV \& (1881) 14, pp. 1-40 \& Tafeln I-II: 12.

${ }^{97}$ Massin, ‘Wilhelmine Germany', p. 109-10.

${ }^{98}$ Myres, ‘Anthropology’, pp. 19-21.

${ }^{99}$ Egon Freiherr von Eickstedt, 'Geschichte der anthropolgische Namengabung und Klassifikation (unter

Betonung von Sudasien’, Zeitschrift für Rassenkunde (1937) 5, pp. 220-82 \& 6, pp. 36-96: 87-88.

${ }^{100}$ Sklenár̆, 500 Years, pp. 82-85.

${ }^{101}$ Michael Hammond, 'Anthropology as a Weapon of Social Combat in Late-Nineteenth-Century France', Journal of the History of the Behavioural Sciences (1980) 16, pp. 118-32: 118.

102 McMahon, Races of Europe, p. 31.

103 ibid.

104 Myres, 'Presidential Address', p. xxvi; Comas, Congresos, p. 47.

105 Ibid, p. 28.

${ }^{106}$ Elazar Barkan, The Retreat of Scientific Racism; Changing Concepts of Race in Britain and the United States between the World Wars, Cambridge: Cambridge University Press, 1992, p. 19.

${ }^{107}$ Massin, ‘Wilhelmine Germany’, pp. 128.

${ }^{108}$ Ibid, pp. 84-85; Proctor, 'Tradition', p. 154.

${ }^{109}$ Myres, 'Anthropology', p. 40; Sklenář, 500 Years, pp. 105 \& 134-35.

${ }^{110}$ MacCurdy, 'Instruction', p. 916; Făcăoaru, 'Antropologia', pp. 210-16.

${ }^{111}$ Eickstedt, 'Geschichte‘, p. 88; Vallois, 'hundertjahrigen’, p. 77.

112 Zimmerman, Germany, pp. 38 \& 112-113.

113 James L. MacLoughlin, 'The Race-Type in Celtic Literature', New Ireland Review (1896) 5(2), pp. 81-94;

6(1), pp. 26-38: 26.

${ }^{114}$ Neil MacMaster, Racism in Europe, Houndsmill: Palgrave, 2001, pp. 8-9.

${ }^{115}$ Eickstedt, 'Geschichte', pp. 42 \& 82; Robert Knox, The Races of Men: A Philosophical Enquiry into the

Influence of Race over the Destinies of Nations: A Fragment, London: Renshaw, 1850, p. 15; Matthew Arnold, Lectures and Essays in Criticism, Ann Arbour: University of Michigan Press, 1962, pp. 298-99. 
116 Manias, Race, p. 111.

117 Tzvetan Todorov, On Human Diversity: Nationalism, Racism, and Exoticism in French Thought, Cambridge: Harvard University Press, 1993, pp. 106-9 \& 114-18, 145 \& 156-59.

118 Mucchielli, 'durkheimiens', pp. 8-12, \& 18-22; Pogliano, L'ossessione, p. 446; Mogilner, Homo Imperii, pp.169-70; MacMaster, Racism, p. 44.

${ }_{119}$ Manias, Race, p. 175.

${ }^{120}$ McMahon, Races of Europe, p. 61.

${ }^{121}$ Ibid, p. 58.

122 Blanckaert, 'Edwards’, p. 48; Mogilner, Homo Imperii, pp.59-60.

${ }^{123}$ Stefan Berger and Alexei Miller (eds), Nationalizing empires. Budapest: Central European University Press, 2015.

${ }^{124}$ Făcăoaru, 'Antropologia', pp. 210-11 \& 215; Frank Spencer, 'The Rise of Academic Physical Anthropology in the United States (1880-1980): A Historical Overview’, American Journal of Physical Anthropology (1981) 56(4), pp. 353-364: 355; Myres, 'Presidential Address’, pp. xxviii-xxix \& 28.

${ }^{125}$ Bunzl and Penny, 'Introduction', p. 11.

${ }^{126}$ Alice L. Conklin, In the museum of man: race, anthropology, and empire in France, 1850-1950, Ithaca:

Cornell University Press, 2013, pp. 2-3.

127 Zimmerman, Germany, pp. 243-44; Evans, Anthropology at war, p. 12.

${ }^{128}$ Barkan, Retreat, pp. 57-58; Dias, Musée, p. 56; Amanda Rees, 'Stories of stones and bones: disciplinarity, narrative and practice in British popular prehistory, 1911-1935', The British Journal for the History of Science (2016) 49(3), pp. 433-51: 437.

${ }^{129}$ Stocking, Ethnographers’ Magic, pp. 351-52; Blanckaert, 'Edwards’, p. 48; Hammond, ‘Anthropology’, pp. $126 \& 128$.

130 Stocking, Victorian Anthropology, pp. 248-49.

${ }^{131}$ McMahon, Races of Europe, p. 61; Dias, Musée, pp. 26-27 \& 56.

132 Hammond, 'Anthropology', p. 129; Stocking, Ethnographers’ Magic, p. 357.

${ }^{133}$ Modesto Sanemeterio Cobo, Les origines de l'École d'Anthropologie de Paris, 1999, http://archive.is/svvH, accessed 22-2-2014.

${ }^{134}$ McMahon, Races of Europe, p. 53.

135 Paul Broca, 'La race celtique ancienne et moderne: Arvernes et Armoricains - Auvergnats et bas-Bretons', Revue d'Anthropologie (1873) 2, pp. 577-628: 591 \& 599.

${ }^{136}$ Dias, 'collections', pp. 208 \& 224; Quine, 'Making Italians’, pp. 130-31 \& 141.

${ }^{137}$ W.H. Flower, 'On the Classification of the Varieties of the Human Species', Journal of the Anthropological Institute of Great Britain and Ireland (1885) 14, pp. 378-95: 378.

138 Alfred Cort Haddon, The Races of Man, London: Cambridge at the University Press, 1924, p. 27; Carlton

Coon, The Races of Europe, New York: Macmillan, 1939, p. 284.

${ }^{139}$ Eugène Pittard, Les Peuples des Balkans: Recherches anthropologiques dans la péninsule das Balkans, spécialement dans la Dobrudja, Geneva: Georg, 1920, p. 10.

${ }^{140}$ Iordache Făcăoaru, 'Amesticul rasial şi etnic in România', Buletinul Eugenic şi Biopolitic (1938) 9(9-10), pp. 276-87: 210-11 ; McMahon, Races of Europe, p. 29.

${ }^{141}$ Blanckaert, 'Edwards', p. 48.

${ }^{142}$ Myres, 'Presidential Address', p. xxvi; Comas, Congresos, p. 66; Pogliano, L'ossessione, p. 42.

143 Blanckaert, 'L’indice', p. 195; MacMaster, Racism, p. 13.

${ }^{144}$ Keane, Ethnology, p. 205; Odom, 'Generalizations’, p. 16.

145 Joseph Deniker, 'Les races européennes', Bulletins de la Société d’Anthropologie de Paris (1897) Ser. 4, 8, pp. 189-208 \& 291-302: 125.

146 Todorov, On Human Diversity, pp. 141 \& 144.

${ }^{147}$ Arthur Keith, 'The Evolution of the Human Races', Journal of the Royal Anthropological Institute of Great Britain and Ireland (1928) 58, pp. 305-21: 310-21; Nicolae Lahovary, Istoria şi o nouă metodă de determinare a rasselor: Incercare de sinteză cu privire la bazele bioantropologice ale istoriei în legatură cu trecutul europei şi al neamului românesc, Bucharest: Cultura Natională, 1927, p. 10; Boleslav Rosiński, 'Spostrzeżenia z pogranicza antropologji i socilogji', Kosmos (1929) Ser. B, 54(2), pp. 265-76: 265.

${ }^{148}$ Pogliano, L’ossessione, pp. 45 \& 492.

${ }^{149}$ Erazm Majewski, 'Rasa a narod: Naród i cywilizacya’, Światowit (1905) 6, pp. 162-71: 164-65.

150 Jan Czekanowski, Antropologia polska w międzywojennym dwudziestoleciu 1919-1939, Warsaw:

Towarzystwo Naukowe Warszawskie: Wydział IV Nauk Biologychnych, 1948, p. 27; Eickstedt, 'Geschichte', p. 82-83.

${ }^{151}$ Kollmann, 'Beitrag', pp. 115-17; Giuseppe Sergi, Specie e Varietà Umane: Saggio di una sistematica antropologica, Turin: Fratelli Bocca, 1900, p. 8. 
152 Hans F.K. Günther, Kleine Rassenkunde des Deutsches Volkes, München: Lehmann, 1933, p. 11; Jan Czekanowski, 'The Racial Structure of Silesia', Baltic and Scandinavian Countries (1937) 3, 2(6), pp. 227-33: 228-30.

${ }^{153}$ Morant, 'Theories’, p. 153; Evola, Sintesi, pp. 34-35.

154 Proctor, 'Tradition', p. 143-45 \& 148; Massin, 'Wilhelmine Germany’, pp. 116 \& 130-31; Puschner, 'Germanenideologie', pp. 87-89; MacMaster, Racism, p. 5-6.

155 Geoffrey G. Field, 'Nordic Racism’, Journal of the History of Ideas (1977) 38(3), pp. 523-40: 528.

${ }^{156}$ Pauline M.H. Mazumdar, 'Blood and Soil: The Serology of the Aryan Racial State', Bulletin of the History of Medicine (1990) 64(2), pp. 187-219: 194; Kühl, Internationale, p. 38; Field, ‘Nordic’, p. 528.

${ }^{157}$ Lutzhöft, Der Nordische Gedanke, p. 23 Zofia Kurnatowska and Stanislaw Kurnatowski, 'Der Einfluss nationalistischer Ideen auf die mitteleuropaeische Urgeschichtsforschung', in Jan M. Piskorski, Joerg Hackmann and Rudolf Jaworski (eds.), Deutsche Ostforschung und polnische Westforschung in Spannungsfeld von Wissenschaft und Politik, Fibre: Osnabrueck, 2002, p. 98; Kossinna, 'Ursprung', pp. 18-19.

${ }^{158}$ Mazumdar, 'Serology’, p. 191; WH. Schneider, ‘The History of Research on Blood Group Genetics: Initial Discovery and Diffusion’, History and Philosophy of the Life Sciences (1996) 18(3), pp. 273-303: 296.

159 Fee, 'Craniology', p. 427.

${ }^{160}$ Friedrich Herz, Rasse und Kultur: Eine kritische Untersuchung der Rassentheorien, Leipzig: Kröner, 1925 , p. 14; Chamberlain, Grundlagen, pp. 313 \& 317-18.

161 Ibid, pp. 313, 317-20.

${ }^{162}$ Marius Turda, 'In search of racial types: soldiers and the anthropological mapping of the Romanian nation, 1914-44’, Patterns of Prejudice (2012) 47(1), pp. 1-21: 4; Malik, Meaning, p. 84; Ivan Hannaford, Race: The History of an Idea in the West, 1996, Washington: Woodrow Wilson Center Press, pp. 349-50.

163 Proctor, ‘Tradition’, p. 138; Alfred Rosenberg, Der Mythos des 20. Jahrhunderts: Eine Wertung der seelischgeistigen Gestaltenkämpfe unsere Zeit, 1930, Munich: Hoheneichen; Julius Evola, Sintesi di dottrina della razza, Milan: Ulrico Hoepli, 1941, pp. 34-35 \& 73-77.

${ }^{164}$ Werner Köster, Die Rede über den “Raum”: Zur sematischen Karriere eines deutschen Konzepts, Heidelberg: Synchron, 2002, p. 74.

${ }^{165}$ Hannajost Lixfeld, Folklore and Fascism: The Reich Institute for German Volkskunde, Bloomington: Indiana University Press, 1994, pp. 12-13 \& 20-21; Sklenáŕ, 500 Years, p. 151.

166 Lixfeld, Folklore, pp. 12-13 \& 20-21.

${ }^{167}$ Włodzimierz Rączkowski, “"Drang nach Westen”?: Polish Archaeology and National Identity’, in Margarita Díaz-Andreu and Timothy Champion, Nationalism and Archaeology in Europe, London: UCL Press, 1996, pp. 189-217: 190-94; Gustaf Kossinna, 'Der Ursprung der Urfinnen und der Urindogermanen und ihre Ausbreitung nach dem Osten’, Mannus (1909-10) 1, pp. 17-52 \& 225-45; 2, pp. 59-108: 18-19.

168 MacMaster, Racism, pp. 42-43; Stefan Kühl, Die Internationale der Rassisten: Aufstieg und Niedergang der internationalen Bewegung für Eugenik und Rassenhygiene im 20. Jahrhundert, Frankfurt: Campus, 1997, pp. 23 \& 54-55.

${ }^{169}$ Făcăoaru, ‘Antropologia', pp. 211-17; Kühl, Internationale, pp. 59 \& 93; Björn M. Felder, ““God forgivesbut Nature never will” Racial Identity, Racial Anthropology, and Eugenics in Latvia 1918-1940’, in Björn M. Felder and Paul J. Weindling (eds), Baltic Eugenics: Bio-Politics, Race and Nation in Interwar Estonia, Latvia and Lithuania 1918-1940, Amsterdam: Rodopi, 2013, pp. 115-46: 129.

${ }^{170}$ Paul Weindling, Health, Race and German Politics between National Unification and Nazism 1870-1945, Cambridge: Cambridge University Press, 1993, p. 7; Massin, ‘Wilhelmine Germany’, pp. 137; Kühl, Internationale, pp. 56-57.

${ }^{171}$ J.T. Klein, Interdisciplinarity, p. 65; D. Alvargonzález, 'Multidisciplinarity, interdisciplinarity, transdisciplinarity, and the sciences’, International Studies in the Philosophy of Science (2011) 25(4), pp. 387403: 393; Daniel J. Kevles, In the Name of Eugenics: Genetics and the Uses of Human Heredity, Berkeley: University of California Press, 1985, pp. 70-72.

172 Gould, Mismeasure, p. 124.

173 Odom, ‘Generalizations', p. 16; MacMaster, Racism, pp. 38-39.

${ }^{174}$ Pogliano, L'ossessione, pp. 34-35; Gould, Mismeasure, p. 162.

175 Gheorghe Popoviciu, 'Asemănări şi diferenţe în structura de rase sanghine a Românilor şi popoarelor conlocuitoare şi învecinate', Dare De Seamă Asupra Şedinţelor: Societăţii Române De Antropologie Din Cluj (1935-1936) , p. 78; Iordache Făcăoaru, 'Valoarea biorasială a naţiunilor europene şi a provinciilor româneşti: O primă încercare de ierarhizare etnică', Buletinul Eugenic şi Biopolitic (1943) 14(9-10), pp. 278-310: 296 ; Al. Manuilă, Originea Neamului Românesc în interpretarea sa biologică, Bucharest: Institutul Statistic, 1943, p. 7; Schneider, 'History', p. 282

${ }^{176}$ McMahon, Races of Europe, p. 39.

${ }^{177}$ William C. Boyd, 'Critique of Methods of Classifying Mankind', in Earl W. Count (ed.), This is Race: An Anthology Selected from the International Literature on the Races of Man, New York: Schuman, 1950, pp. 637- 
53: 642; Jonathan Marks, 'The legacy of serological studies in American physical anthropology', History and Philosophy of the Life Sciences (1996) 18(3), pp. 345-62: 353; Pogliano, L'ossessione, pp. 102 \& 396-97.

${ }^{178}$ L. Hirschfeld and H. Hirschfeld, 'Essai d'application des méthodes sérologiques au problème des races', L'Anthropologie (1918) 29, pp. 505-37: 509, 518 \& 535-36.

${ }^{179}$ Pogliano, L'ossessione, pp. 33 \& 100; Olga C. Necrasov, Etude Anthropologique de la Moldavie et de la Bessarabie Septentrionales, Bucharest: Imprimerie nationale, 1941, pp. 132 \& 136; Schneider, 'History’, p. 285.

${ }^{180}$ MacMaster, Racism, pp. 35-41; Kevles, Genetics, p. 46; Majewski, 'Rasa a narod', pp. 162-63.

${ }^{181}$ Massin, 'Wilhelmine Germany', p. 130.

182 Field, 'Nordic’, pp. 524-26; Jan Czekanowski, Człowiek w czasie i przestrzenie, Warsaw: Państwowe Wydawnictwo Naukowe, 1967, p. 47; Lutzhöft, Nordische Gedanke, pp. 21 \& 92.

183 Proctor, 'Tradition', pp. 146 \& 157; Czekanowski, Człowiek, p. 48.

${ }^{184}$ Proctor, 'Tradition', pp. 158-69; Coon, Races, p. 286.

185 McMahon, Races of Europe, p. 56.

${ }^{186}$ Eickstedt, Forschung, pp. 140-41; Kühl, Internationale, pp. 34, 50, 53, 58-60, 66-68 \& 87; Felder, 'Latvia', p. 120.

${ }^{187}$ McMahon, Races of Europe, pp. 59-64. I explore the reasons in Races of Europe, p. 60-64 and

'Transnational Race Classification: Scientific network and system of narratives', in Richard McMahon (ed.),

National Races: Scientific classification and political identity, Lincoln: University of Nebraska Press,

forthcoming.

${ }^{188}$ McMahon, Races of Europe.

189 T. Bielicki, T. Krupinski and J. Strzalko, 'History of Physical Anthropology in Poland', International Association of Human Biologists, Occasional Papers (19851) 6: 7.

${ }^{190}$ Ilse Schwidetzky, 'Die Rassenforschung in Polen', Zeitschrift für Rassenkunde und ihre Nachbargebiete (1935) 1, pp. 76-83, 136-204 \& 289-314: 140-41.

191 ibid.

192 Collis, John, 2003, The Celts: Origins, Myths \& Inventions, Stroud: Tempus, pp. 86 \& 151; Kurnatowska and Kurnatowski, 'Urgeschichtsforschung’, pp. 97-98; Sklenáŕ, 500 Years, p. 151.

193 Jan Czekanowski, 'Sto Lat Antropologii Polskiej 1856-1956: Osrodek Lwowski’, Materiały i Prace Antropologiczne (1956) 34, pp. 41-42; Schwidetzky, 'Polen’, pp. 152, 162-64, 199 \& 302.

${ }^{194}$ Marks, 'legacy', p. 346.

195 Pogliano, L'ossessione, p. 47; Mazumdar, 'Serology’, p. 193. Eastern German concentrations of group B therefore 'proved' Slav influence (Petru Râmneanţu, 'Distribuţia grupelor de sînge la populaţia din Transilvania’, Buletinul Eugenic şi Biopolitic (1941) 12(9-12), pp. 137-59: 147).

196 Rees, 'stones and bones', p. 450.

197 McMahon, Races of Europe, pp. 48-50. 